\title{
LINE Chatbot Informasi Cuaca Wilayah Indonesia
}

\author{
Junadhi $^{1}$,Mardainis ${ }^{2}$ \\ ${ }^{1,2}$ Program Studi Sistem Informasi STMIK Amik Riau \\ Jl. Purwodadi Km. 10 Panam, Pekanbaru, Riau, telp. 0761589561

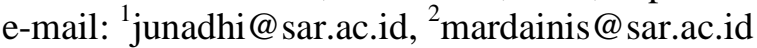

\begin{abstract}
Abstrak
Indonesia termasuk negara beriklim tropis yang memiliki cuaca hujan dan panas. Perubahan musim kadang kala terjadi berubah ubah sehingga sulit di prediksi. Pada waktu kita akan melakukan perjalanan ke suatu daerah, sebaiknya kita mengetahui situasi dan cuaca di daerah yang dituju dan daerah daerah yang akan dilewati selama perjalanan agar terhindar dari kendala perjalanan berupa banjir, angin ribut dan tanah longsor. Selama ini informasi ramalan cuaca bisa didapatkan melalui berita di televisi ataupun radio, hal ini menyulitkan bagi masyarakat untuk mengetahui informasi cuaca saat ini pada suatu daerah jika dalam perjalanan. Peneliti membangun sebuah aplikasi informasi cuaca saat ini yang dapat diakses melalui smartphone dengan memanfaatkan sosmed LINE. Hanya dengan mengetikkan permintaan informasi cuaca melalui chat di sosmed LINE, aplikasi akan menjawab informasi cuaca yang dibutuhkan. Jika kita sudah mengetahui situasi cuaca di daerah yang akan dituju dan daerah daerah yang akan dilewati selama perjalanan, kita akan mudah memutuskan apakah jadi berangkat atau tidak, ataupun mempersiapkan diri untuk mengantisifasi keadaan yang akan terjadi.Penelitian ini memberikan kemudahan bagi pemakai untuk mengetahui cuaca suatu daerah hanya dengan membuka aplikasi chatbot yang digunakan diatas aplikasi sosmed LINE.
\end{abstract}

Kata kunci: perjalanan, Informasi, cuaca, chatbot, line

\begin{abstract}
Indonesia is a tropical country that has rainy and hot weather. Seasonal changes sometimes change, making it difficult to predict. When we are going to travel to an area, we should know the situation and weather in the destination area and the area that will be passed during the trip to avoid the obstacles of travel in the form of floods, hurricanes and landslides. During this time the weather forecast information can be obtained through news on television or radio, this makes it difficult for the public to know the current weather information on an area if on the trip. The researcher built a current weather information application that can be accessed via a smartphone using social media LINE. Only by typing in weather information requests via chat on Social Media LINE, the application will answer the weather information needed. If we already know the weather situation in the area to be addressed and the area to be passed during the trip, we will easily decide whether to go or not, or prepare to anticipate the situation that will occur. This study makes it easy for users to know the weather area just by opening the chatbot application used above the sosmed LINE application.
\end{abstract}

Keywords: travel, forecast, weather, chatbot, line.

\section{Pendahuluan}

Pengembangan sistem informasi dilakukan oleh berbagai organisasi untuk pemenuhan kebutuhan informasi, baik untuk kegiatan operasional maupun untuk pelayanan publik. Dalam pengembangan sistim informasi saat ini, banyak sistem yang dikembangkan mampu bekerja sendiri tanpa selalu dioperasikan oleh admin, sebagai contoh aplikasi chatbot yang berfungsi sebagai mesin penjawab mampu memberikan informasi ke yang membutuhkan tanpa perlu dioperasikan oleh operator. Sistem bekerja secara otomatis dan memberikan jawaban sesuai dengan pertanyaan yang diajukan melalui chat. Pengembangan sistem berpedoman pada 
metodologi pengembangan sistem informasi dengan merencakan, mengelola, mengendalikan dan mengevaluasi hasil dari pengembangan sistem.[1].

Chatbot merupakan aplikasi komputer yang digunakan untuk melakukan percakapan lewat tulisan. Cara kerja chatbot mirip seperti mesin penjawab telepon yang banyak digunakan pada kantor kantor dengan fasilitas dial up. Pertanyaan yang mampu dijawab oleh aplikasi chatbot adalah pertanyaan yang bersifat umum dan sudah dipersiapkan jawabannya. [2]. Manfaat dari chatbot adalah untuk pelayanan informasi kepada pengguna tanpa melibatkan operator sebagai penjawab, jadi pekerjaan operator sudah di alihkan ke aplikasi chatbot[3]. Untuk pemakaiannya aplikasi chatbot ini biasanya dapat dipanggil melalui aplikasi lain seperti LINE.Dalam pemakaiannya chatbot digunakan sebagai mesin penjawab yang menggunakan teks atas informasi yang dibutuhkan. Dikatakan sebagai mesin penjawab karena fungsi dari chatbot itu sendiri adalah sebagai pengganti manusia untuk menjawab chat terhadap pertanyaan pertanyaan yang sering ada dan telah disiapkan jawabannya. Jawaban dari pertanyaan tersebut disimpan dalam database dan akan digunakan apabila ada pertanyaan yang masuk. Salah satu contoh penerapan chatbot pernah dibahas oleh Enterprise, Jubilee(2018) dalam bukunya berjudul "Teknik Memasang Chatbot pada Toko Online". Pembeli bisa melakukan cek harga maupun persediaan terhadap satu jenis barang dengan melakukan chat menggunakan aplikasi chatbot, sistem akan memberikan jawaban sesuai dengan pertanyaan yang diajukan[4]. Sementara itu, Bahartyan dan Waspada (2016) melakukan penelitian dalam jurnalnya berjudul Integrasi Chatbot Berbasis Aiml Pada Website E-Commerce Sebagai Virtual Assistant Dalam Pencarian Dan Pemesanan Produk (Studi Kasus Toko Buku Online Edu4Indo.Com). Membahas pada web E-Comerse yang mereka bangun juga dilengkapi aplikasi pelayanan informasi chatbot bagi pengunjung yang akan menanya harga produk beserta persediaannya[5].

Salah satu media sosial yang banyak digunakan oleh masyarakat untuk berkomunikasi adalah aplikasi LINE. Aplikasi ini juga memiliki fasilitas antara lain untuk mengirim pesan teks yang bisa dilengkapi stiker lucu, mengirim pesan suara, mengirim foto, panggilan suara dan panggilan video. Disamping itu aplikasi LINE juga mampu mengirim file dokumen. Aplikasi LINE juga mampu melayani pengguna untuk berkomunikasi dalam group. Pengguna aplikasi LINE di dunia tercatat 220 juta dan 90 juta pengguna berasal dari Indonesia. Pengguna aplikasi LINE di Indonesia pada umumnya berasal dari kalangan muda dan kreatif, hal ini disebabkan banyaknya fitur fitur yang disediakan LINE sesuai dengan gaya hidup anak muda (Nurrahman, 2017). Dalam pemakaiannya LINE juga memberi hak akses bagi develeper yang ingin mengembangkan aplikasi dan bisa diakses oleh pengguna LINE. Saat ini Indonesia merupakan pengguna sosial media LINE terbesar ketiga setelah Jepang dan Taiwan (Ayuningtias (2017). Pengguna LINE di Indonesia berasal dari kalangan anak muda berumur 18-25 tahun, umur ini biasanya ada pada kalangan mahasiswa[6].

Informasi cuaca penting dalam kehidupan kita saat ini untuk merencanakan kegiatan kedepan, seperti melakukan perjalanan, mengolah lahan pertanian dan lain sebagainya. Jika kita tau informasi cuaca saat ini baik didaerah sendiri maupun didaerah lain, kita bisa melakukan persiapan untuk menghadapi hal tersebut[7]. Salah satu lembaga yang mengolah informasi cuaca di Indonesia adalah Badan Meterologi Klimatologi dan Geofisika (BMKG). Salah satu tugas badan ini adalah memberikan informasi cuaca. Banyak penlitian yang telah dilakukan oleh peneliti mengenai cuaca, termasuk Pengembangan aplikasi tentang penyampaian informasi Informasi cuaca, beberapa diantaranya adalah penelitian Purwanto, (2013) Aplikasi Berbasis SMS Gateway Yang Dapat Memberikan Informasi Tentang Gempa Bumi Dan Informasi Cuaca Pada BMKG Semarang. Hasil dari aplikasi ini dapat menghasilkan informasi tentang gempa bumi yang terjadi dan informasi cuaca dari BMKG Semarang hanya dengan mengirimkan SMS. Pengembangan aplikasi yang telah dilakukan tersebut masih memiliki kekurangan dalam hal keterbatasan akses dan biaya untuk mengirim sms. Penelitian kedua dilakukan oleh Eryx dan Ajib (2018) dengan judul Aplikasi Informasi Cuaca Di Lokasi Pariwisata Provinsi Jawa Tengah Berbasis Web Mobile [8]. Hasil dari aplikasi ini adalah pengguna bisa memperoleh informasi cuaca dengan membuka web yang sudah bisa diakses dari smartphone. Pada tahun 2018 Pande Gede Wipradnyana dari universitas Udayana melakukan penelitian untuk mengembangkan 
sebuah aplikasi informasi prakiraan cuaca wilayah Bali pada sistem operasi Android, diharapkan dapat membantu masyarakat untuk dapat mengetahui informasi cuaca khususnya di daerah wisata Bali secara lebih cepat dan mudah dimanapun dan kapanpun lewat ponsel berbasis Android[9].

Namun pada penelitian ini peneliti akan membangun aplikasi chatbot informasi cuaca yang bisa diakses melalui media sosial LINE. Penelitian ini mengembangkan sebuah aplikasi informasi cuaca wilayah kota besar yang ada di Indonesia pada layanan aplikasi LINE, diharapkan dapat membantu masyarakat untuk dapat mengetahui informasi cuaca secara lebih cepat dan mudah dimanapun dan kapanpun lewat ponsel berbasis Android dan IOS. Dalam pemakaiannya aplikasi chatbot informasi cuaca ini akan dijalanan diatas platform LINE. Untuk mengetahui informasi cuaca didaerah yang diinginkan maka cukup dengan mengirim chat melalui aplikasi ini, selanjutnya aplikasi akan mencari jawabannya dalam database yang ada dan selanjutnya akan mengirim chat balasan sebagai jawaban atas pertanyaan sebelumnya. Proses pengiriman chat balasan dilakukan sepenuhnya oleh aplikasi sebagai pengganti tugas manusia. Kecuali bila jawaban dari pertanyaan yang diajukan belum ada, maka pertanyaan tersebut akan disimpan untuk selanjutnya dibaca oleh admin. Admin akan mengirim chat balasan sebagai jawaban dari pertanyaan sebelumnya.

\section{Metode Penelitian}

Tahapan penelitian yang dilakukan ada 5 (lima) tahap seperti yang ditampilkan pada gambar 1. berikut:

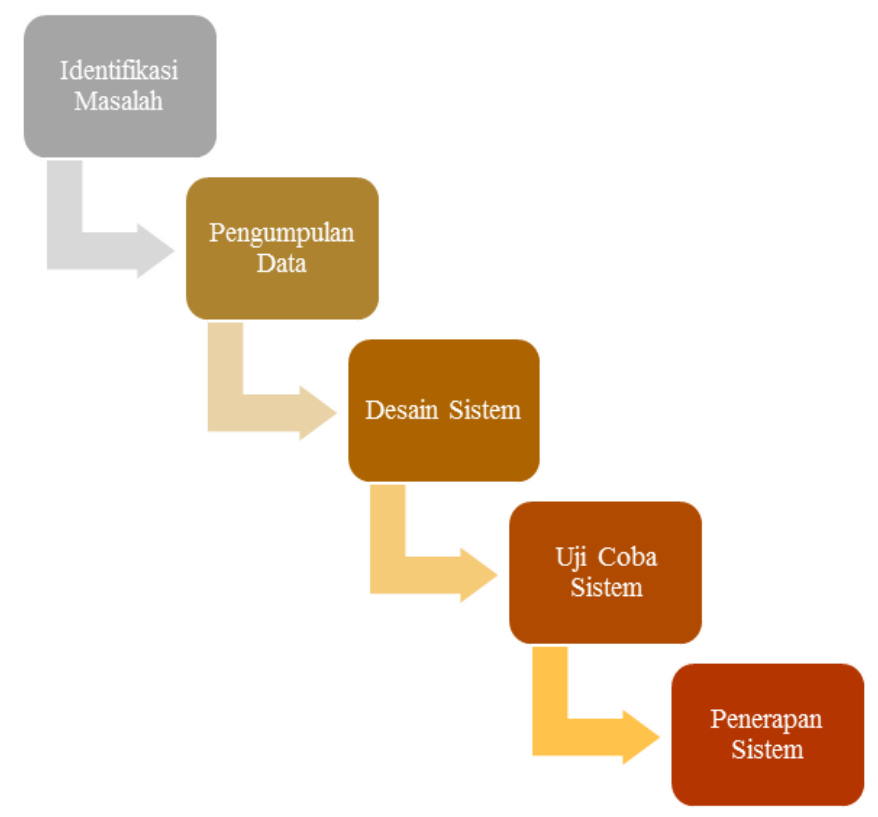

\section{Gambar 1. Tahapan Penelitian}

Tahapan penelitian dilakukan seperti gambar diatas yang terbagi menjadi beberapa proses, yaitu:

1. Pendefinisian masalah dilakukan untuk memahami masalah yang akan dikerjakan, untuk lebih memahami masalah yang ada sehingga dapat dibuat rumusan masalah.

2. Pengumpulan data dilakukan dengan mencari literatur dan informasi pendukung dalam membangun aplikasi chatbot.

3. Desain sistem dilakukan untuk merancang sistem yang akan dibangun mulai dari desain interface tampilan dari aplikasi chatbot yang dibuat. 
4. Pengujian chatbot yang telah dibuat dan dilakukan pengujian dengan cara memasukkan kata kunci yaitu "/cuaca nama_kota", pada aplikasi LINE dan dijalankan pada perangkat smartphone berbasis Android dan IOS.

5. Sistem yang telah di uji coba dan hasilnya baik maka channel chatbot akan diterapkan pada aplikasi LINE dan channel tersebut dapat di tambahkan oleh user yang menggunakan LINE.

\section{Hasil dan Pembahasan}

3.1 Pembahasan

LINE memberikan fasilitas untuk membuat akun bisnis yang dapat digunakan untuk mengirim pesan ke customer dan juga berkomunikasi langsung dengan pelanggan. Komunikasi tersebut bisa berbentuk chat langsung maupun dengan menggunakan pesan auto reply dan keyword reply. Messaging API dapat membuat respon yang dapat disesuaikan dengan kebutuhan khusus yang tak tertangani fitur auto reply dan keyword reply standar. Melalui penggunaan Messaging API, dapat berkirim informasi antara server kita dengan aplikasi LINE pengguna melalui platform LINE.

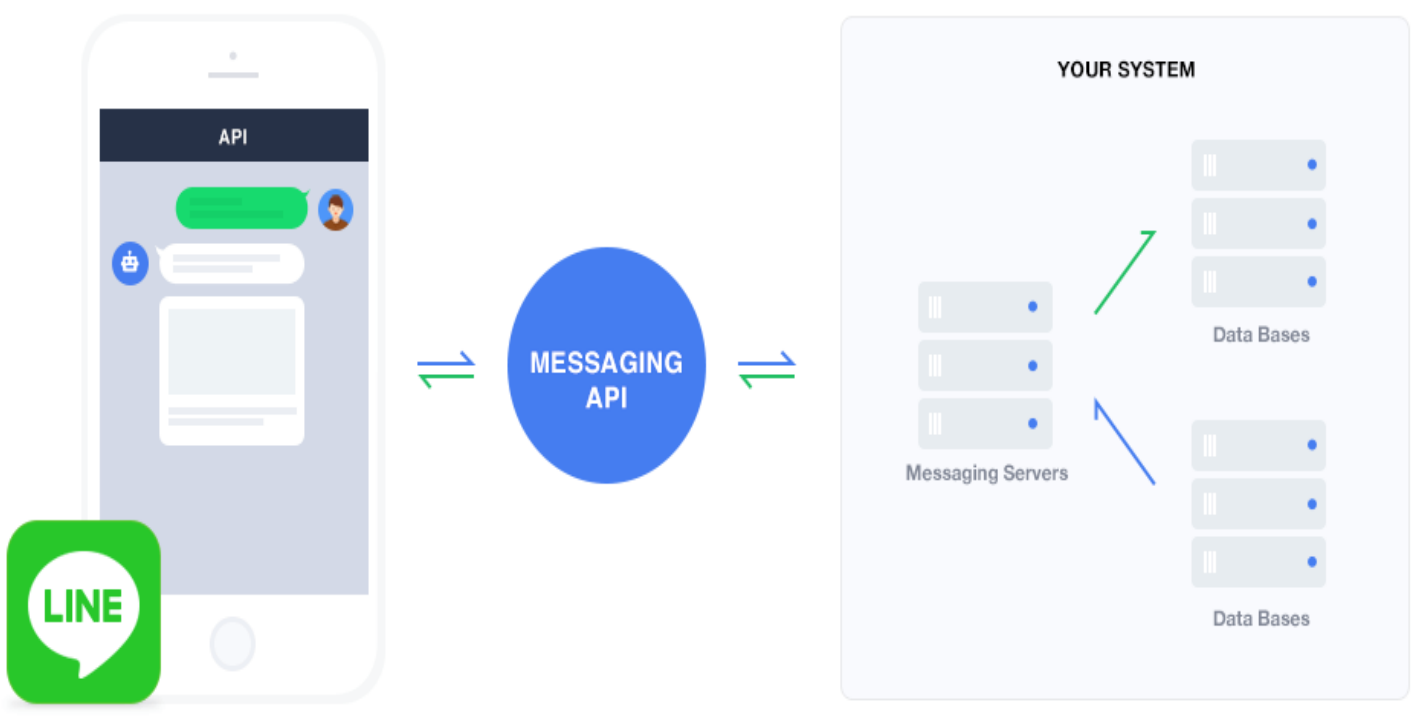

Gambar 2. Cara Kerja Chatbot

LINE platform akan mengirimkan informasi ke server setiap kali ada interaksi antara pengguna dengan akun yang telah dibuat. Ada dua jenis interaksi:

1. Pengguna mengirimkan pesan.

2. Pengguna melakukan sebuah aksi (operasi), seperti menjadikan akun bisnis sebagai teman.

Informasi dikirim dalam format JSON melalui protokol HTTPS ke URL yang sudah didaftarkan sebagai webhook. Struktur data JSON yang dikirim akan bervariasi tergantung dari jenis pesan atau operasi. Setiap request menyertakan kode access token yang digunakan untuk memverifikasi bahwa request yang diterima adalah benar-benar dari platform LINE. Jika access token tidak dikenali, maka request dianggap tidak valid.

Ada beberapa fitur yang dapat dimanfaatkan pada Messaging API, di antaranya:

1. Push Message

Mengirim pesan langsung kepada pengguna yang sudah berteman dengan akun bot.

2. Reply Message

Membalas pesan yang dikirim oleh pengguna ke akun bot. Notifikasi terkait aksi yang dilakukan oleh pengguna akan dikirimkan ke URL webhook. 
3. Imagemap Message

Mengirim gambar dengan teks dan tautan didalamnya. Imagemap dapat digunakan untuk mengirim konten seperti kupon, promo spesial, berita pengumuman, dan posting blog.

4. Template messages

Mengirimkan pesan dengan bentuk dan format yang beragam, seperti gambar, teks, opsi pilihan dan tombol.

5. Menjalankan Bot di Room dan Group

Berinteraksi dengan pengguna di dalam grup seperti halnya chat ke personal.

\subsection{Rancangan Chatbot}

Tahap rancangan chatbot merupakan rancangan yang meliputi proses pengumpulan dan analisis data. Chatbot yang dibangun menggunakan bahasa pemrograman php dengan menggunakan API Key yang disediakan oleh https://openweathermap.org/api. File diunggah pada GitHub.com yang merupakan layanan penggunangan web bersama untuk proyek pengembangan perangkat lunak yang menggunakan sistem pengontrol versi Git dan layanan hosting internet. Berikut ini adalah tampilannya:

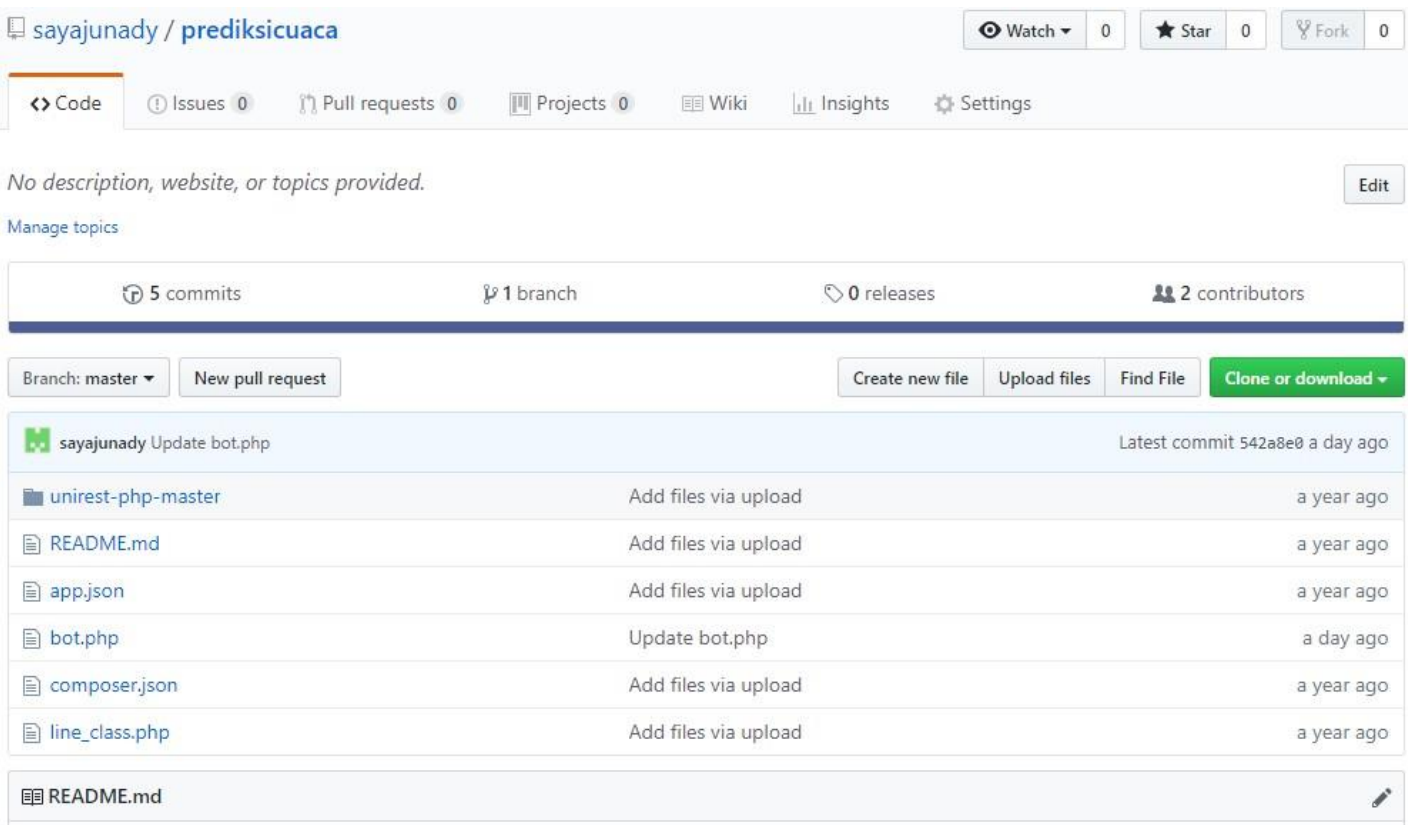

Gambar 3. Sourcode yang di Upload pada Layanan GitHub

Selanjutnya dilakukan rancangan terhadap chatbot yang dibangun yang dapat dilihat pada tabel dibawah ini.

Tabel 1. Rancangan Chatbot

\begin{tabular}{|l|l|}
\hline Nama Bot & Cuaca Hari Ini \\
\hline Deskripsi & $\begin{array}{l}\text { Merupakan chatbot yang menyediakan layanan untuk } \\
\text { mengetahui prakiraan cuaca di wilayah Indonesia. }\end{array}$ \\
\hline Fitur & Cuaca hari ini \\
\hline Greeting Message & $\begin{array}{l}\text { Terima kasih telah menambahkan kami sebagai teman, kamu } \\
\text { bisa dapatkan info terbaru tentang informasi cuaca di wilayah } \\
\text { Indonesia. }\end{array}$ \\
\hline $\begin{array}{l}\text { On Boarding } \\
\text { Message }\end{array}$ & $\begin{array}{l}\text { Terimakasih sudah terhubung dengan kami. Kami bisa bantu } \\
\text { kamu cari info terbaru tentang informasi cuaca. }\end{array}$ \\
\hline
\end{tabular}


Pada tahap ini dilakukan pengumpulan informasi yang sering dibutuhkan oleh user. Informasi ini membutuhkan variabel yang sesuai yang bersumber dari API Key yang disediakan oleh https://openweathermap.org/api sebagai penyedia informasi cuaca. Selanjutnya dibuat pertanyaan pertanyaan yang mungkin akan diajukan oleh user melalui media input pada aplikasi chatbot. Jawaban yang diberikan disesuaikan dengan pertanyaan yang diajukan[10].

\subsection{Hasil}

Sebelum aplikasi chatbot innformasi cuaca bisa digunakan pada LINE terlebih dahulu dilakukan beberapa tahap berikut ini :

1. Konfigurasi Channel

Sebelum channel chatbot bisa dijalankan maka ada beberapa hal yang harus di konfigurasi seperti pada gambar 3. dibawah ini:

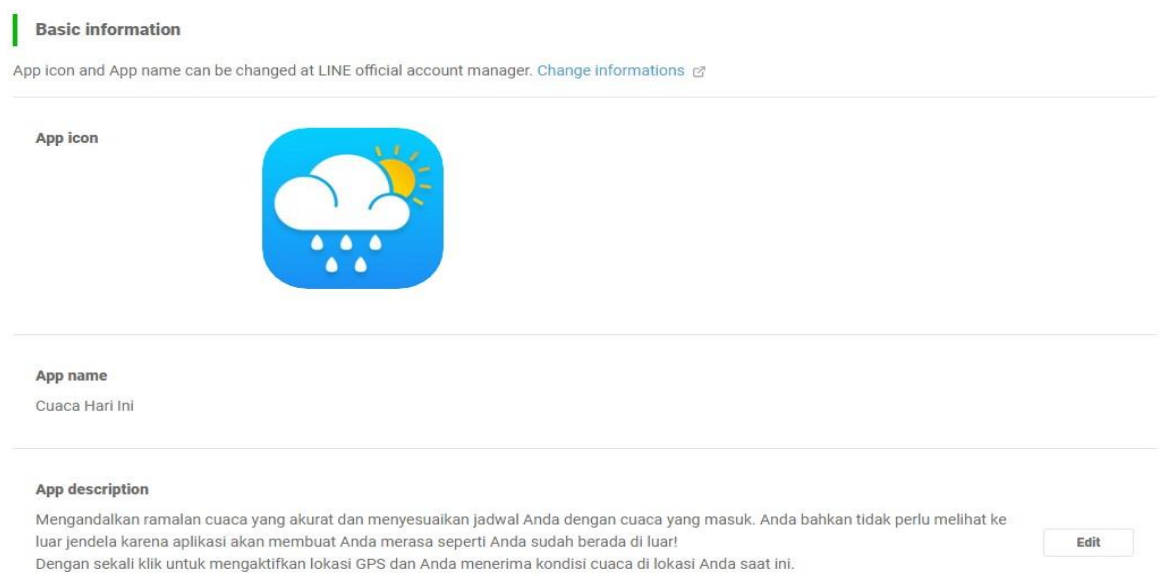

Gambar 3. Halaman LINE Developers

Lakukan generate channel access token yang nanti digunakan untuk autentikasi aplikasi bot. Klik tombol Issue untuk mendapatkan kodenya. Selanjutnya, atur Use webhooks menjadi Enabled. Pada konfigurasi Webhook URL biarkan kosong terlebih dahulu. Webhook URL akan diisi setelah aplikasi yang dibuat telah di-deploy ke web server. Pada bagian Allow Bot to join group chat, pilih opsi Enabled bila bot yang akan dibuat dapat mengakomodasi fitur interaktivitas di dalam grup. Sebaliknya bila tidak ingin menggunakannya, maka sebaiknya diset ke Disabled.

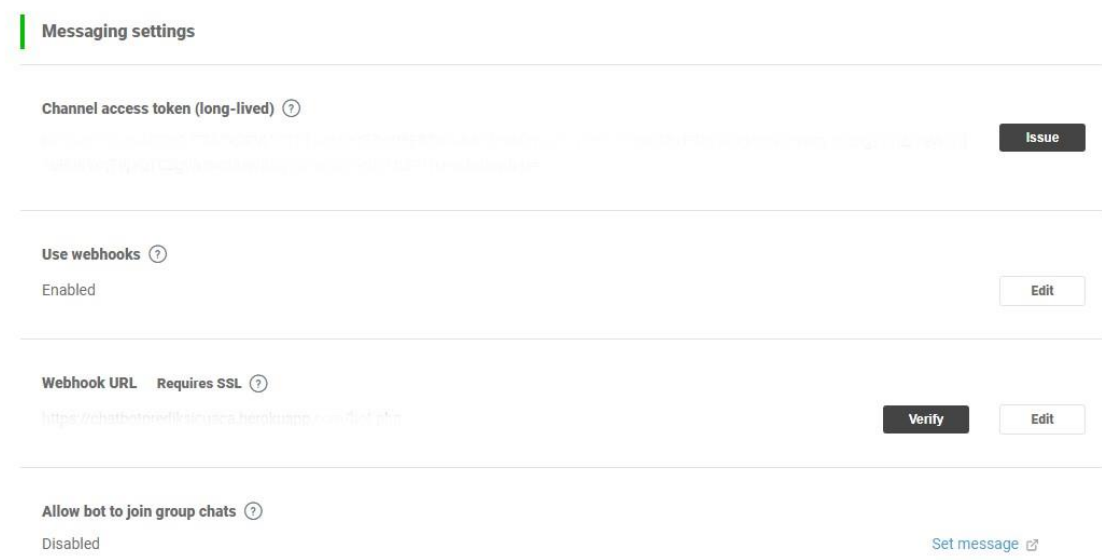

Gambar 4. Pengaturan Pesan 
Pada bagian Using LINE@ features, atur semua pengaturan menjadi Disabled. Hal ini karena kita akan menggunakan Messaging API untuk membalas pesan. Hal tersebut dapat dilihat pada gambar 5.

Using LINE@ features

Message text for LINE@ features are set on the LINE@ Manager.

Auto-reply messages (?)

Enabled

Set message $\square$

Greeting messages (?)

Enabled

\section{Gambar 5. LINE Features}

Untuk menambahkan akun chatbot yang telah dibuat pengguna dapat melakukan Scan QR Code seperti yang ditampilkan pada gambar 6 dibawah ini:

\section{QR Code Chatbot}

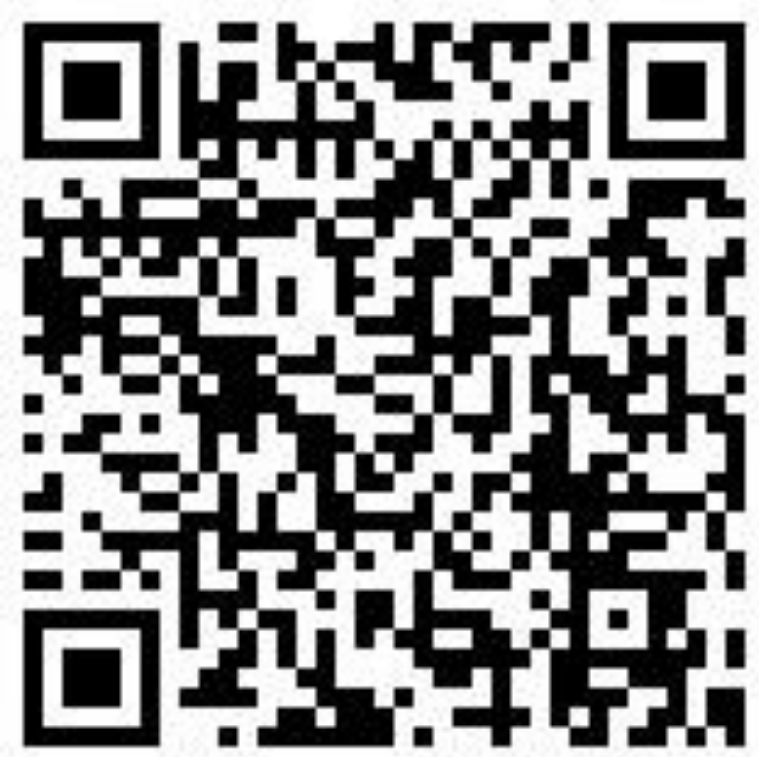

Gambar 6. QR Code Chatbot

\section{Akun chatbot}

Setelah ditambahkan melalui QR Code maka akan masuk dalam list chat aplikasi LINE, seperti gambar dibawah ini, Apabila tampilan seperti diatas sudah muncul pada aplikasi LINE, untuk menggunakan chatbot informasi cuaca bisa dilakukan dengan melakukan klik pada ikon cuaca hari ini dengan gambar ikon awan dan hujan. 


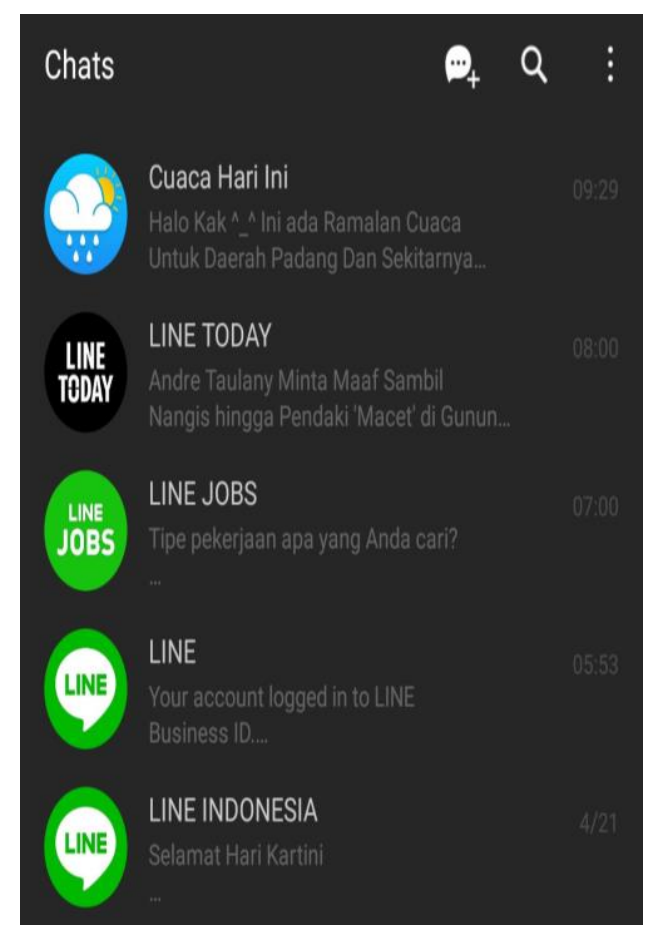

\section{Gambar 7. Akun Chatbot Cuaca Hari Ini}

4. Format Template Message

Untuk menggunakan aplikasi chatbot informasi cuaca klik ikon dengan gambar awan dan hujan, selanjutnya akan tampil dilayar seperti gambar 8 maka pengguna siap untuk mencari tahu informasi cuaca pada suatu daerah dengan mengikuti format template message yang digunakan untuk mengetahui cuaca di setiap wilayah yaitu: /cuaca nama_kota dan dapat dilihat pada gambar dibawah ini yang memperlihatkan adanya permintaan informasi cuaca untuk beberapa daerah, seperti Pekanbaru, Bandung dan Padang.

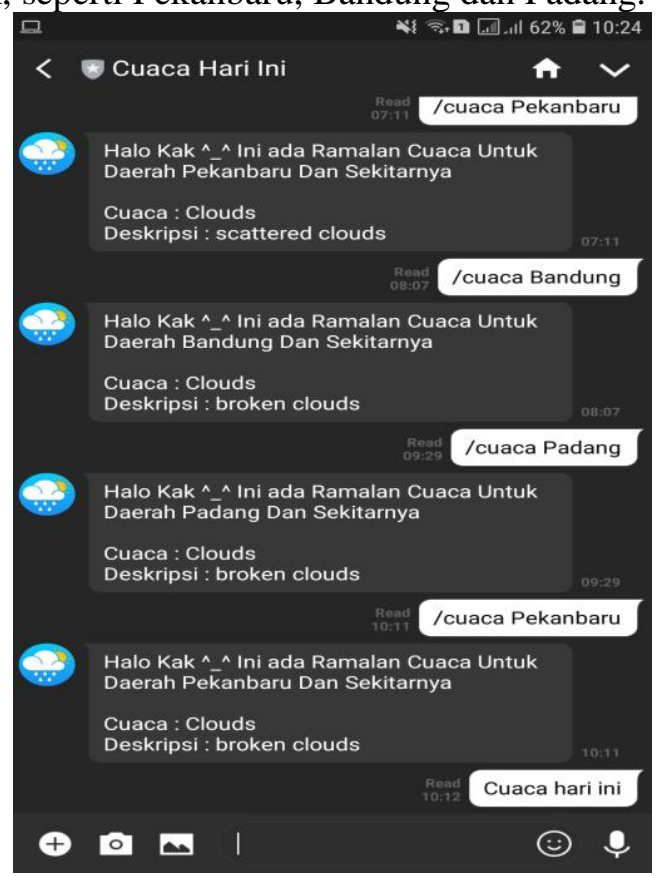

Gambar 8. Format Templat Message 


\section{Kesimpulan}

Dari hasil pembahasan diatas, Aplikasi hanya bisa digunakan sebagai penyampaian informasi cuaca panas dan hujan yang sedang terjadi untuk seluruh wilayah Indonesia. Dalam pemakaian aplikasi untuk meminta informasi cuaca pada suatu daerah, cukup dengan mengirimkan pesan melalui aplikasi berupa pertanyaan cuaca suatu daera, maka aplikasi akan menjawab sesuai dengan kondisi cuaca yang terjadi didaerah tersebut. Dengan menggunakan aplikasi chatbot informasi cuaca ini, kita akan mudah mendapatkan informasi daerah yang akan dituju sebelum melakukan perjalanan, sehingga kita bisa mempersiapkan diri sebelum menuju kelokasi tersebut. Sebagai contoh "Apabila di daerah yang dituju sedang terjadi hujan, maka kalau kita akan kesana antisipasi yang dilakukan dengan membawa payung, tetapi apabila disana sedang banjir maka kita tidak perlu kesana". Aplikasi ini tidak bisa digunakan untuk memprediksi cuaca yang akan terjadi nanti atau besok.

\section{Daftar Pustaka}

[1] P. . Samiaji Sarosa, SE, M.Info.Sys., Metodologi Pengembangan Sistem Informasi, 1st ed. Jakarta, 2017.

[2] D. Suryani and E. L. Amalia, "Aplikasi Chatbot Objek Wisata Jawa Timur Berbasis AIML," SMARTICS J., vol. 3, no. 2, pp. 47-54, 2017.

[3] E. Nila and I. Afrianto, "Rancang Bangun Aplikasi Chatbot Informasi Objek Wisata Kota Bandung Dengan Pendekatan Natural Language Processing," J. Ilm. Komput. dan Inform., vol. 4, no. 1, pp. 49-54, 2015.

[4] J. Enterprise, Teknik Memasang Chatbot di Toko Online. Jakarta - Indonesia: Elex Media Komputindo, 2018.

[5] E. Bahartyan, N. Bahtiar, and I. Waspada, "Integrasi Chatbot Berbasis Aiml Pada Website E-Commerce Sebagai Virtual Assistant Dalam Pencarian Dan Pemesanan Produk (Studi Kasus Toko Buku Online Edu4Indo.Com)," J. Masy. Inform., vol. 5, no. 10, pp. 34-43, 2016.

[6] C. A. Boeky, E. Juvano, M. Reviano, M. E. Rahmat, and R. Subagja, "PENGARUH MEDIA SOSIAL LINE GROUP TERHADAP EFEK SOSIAL," vol. 5, no. 1, pp. 55-65, 2019.

[7] F. Diani, S. Si, M. T. H. Permana, P. S. N, J. Teknik, and P. N. Bandung, "Kajian Sistem Informasi Prakiraan Cuaca Bmkg Pada Bmkg Bandung," vol. 2012, no. 66, pp. 15-16, 2012.

[8] J. Nakula and I. N. Semarang, "Aplikasi informasi cuaca di lokasi pariwisata provinsi jawa tengah berbasis web mobile."

[9] P. G. Wipradnyana, I. M. A. Suyadnya, N. Made, A. Esta, and D. Wirastuti, "APLIKASI PRAKIRAAN CUACA WILAYAH BALI," vol. 5, no. 2, pp. 11-18, 2018.

[10] F. Azwary, F. Indriani, and D. T. Nugrahadi, "Question Answering System Berbasis Artificial Intelligence Markup Language Sebagai Media Informasi," Kumpul. J. Ilmu Komput., vol. 04, no. 01, pp. 48-60, 2016. Creative Commons Attribution International (CC BY-SA 4.0) 